\title{
STRENGTH PARAMETERS OF MASONRY WALLS IN MODELLING HISTORIC CONSTRUCTIONS
}

\author{
Michał GOŁĘBIEWSKI ${ }^{1}$, Izabela LUBOWIECKA, Marcin KUJAWA \\ Gdańsk University of Technology, Faculty of Civil and Environmental Engineering, \\ Gdańsk, Poland
}

\begin{abstract}
The paper presents the determination of the basic material properties of a historic brickwork. Experimental studies were used to identify the basic material properties of bricks. The mechanical properties of the masonry, as an orthotropic homogenized material, were calculated. Then, numerical simulations using the Finite Element Method (FEM) were performed to verify the experimental outcomes. Macromodels with element sizes of 40, 20, 10 and $5 \mathrm{~mm}$, and a micromodel with an element size of $5 \mathrm{~mm}$ were applied. The results were compared with experimental data and results available in literature.
\end{abstract}

Keywords: historic brick walls, masonry structures, homogenization, FEM modeling

\section{INTRODUCTION}

The aim of studies presented in the work is determining the basic material properties of the brick masonry walls of a Gothic church located in Gnojewo near Malbork (Fig. 1). These parameters are used to assess the technical condition of the building, and especially the masonry part of the construction. The analyzed building is a currently closed down evangelical church, built in 1323 in half timbered structure, was rebuilt numerous times over the years until the XIX century.

\footnotetext{
${ }^{1}$ Corresponding author: Gdańsk University of Technology, Faculty of Civil and Environmental Engineering, Gabriela Narutowicza st 11/12, 80-233 Gdańsk, Poland, e-mail: micgoleb@pg.gda.pl, tel.+48583486149
} 


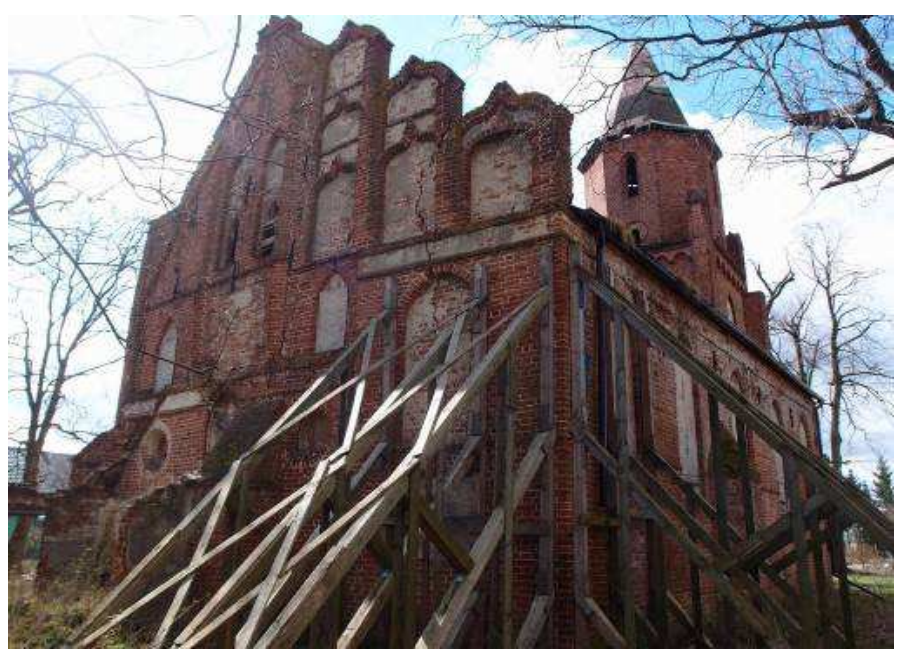

Fig. 1. Church in Gnojewo

\section{STRENGTH PARAMETERS OF WALL COMPONENTS}

The structure under study was constructed of bricks measuring $8 \times 15 \times 30 \mathrm{~cm}$. In order to determine the modulus of elasticity and compressive strength of the material, uniaxial compression tests were done in accordance with the PN EN 772-1 norm. Due to the bad technical condition of the bricks, $50 \mathrm{~mm}$ cubic samples were cut out from them using abrasive waterjet cutting. Strength tests were carried using a Zwick/Roell Z 400 strength testing device.

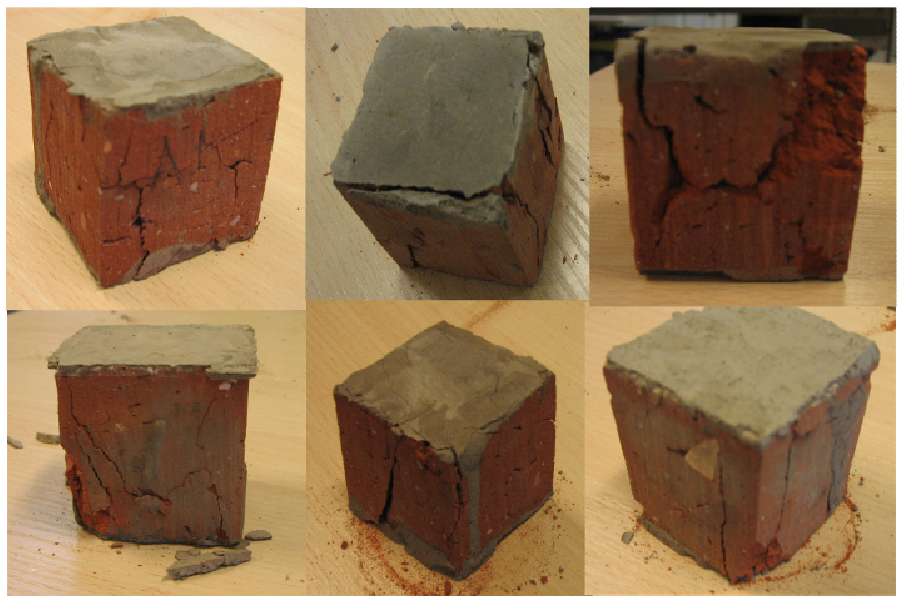

Fig. 2. Samples after testing 
Based on tests carried out on 6 samples (Fig. 2 and 3), the average value of the modulus of elasticity was determined for the bricks, $E_{b}=2.104 \mathrm{GPa}$. This result falls into the range obtained in work [5], in which values for the modulus of elasticity of bricks of a campanile from the turn of the XVI and XVII centuries fell in the range of $E_{b}=2.050-5.300 \mathrm{GPa}$. These values differ significantly from the modulus of elasticity of modern-day bricks determined by Page [6] to be at the level of $E_{b}=7.55 \mathrm{GPa}$ or in work [7] at the level of $E_{b}=12.50 \mathrm{GPa}$.

N-EN 772-1, attachment A, table A1 provides coefficients accounting for the influence of the shape of the tested samples on the strength of bricks determined on the basis of compression tests. For cubic samples with sides measuring 50 $\mathrm{mm}$, the normalized compressive strength of the bricks was calculated applying the coefficient $\delta=0.85$.

$$
f_{b}=\delta \cdot f_{B}=0.85 \cdot 5.338=4.537 \mathrm{MPa}
$$

where: $f_{b}$ - normalized compressive strength of bricks,

$\delta$ - normative coefficient,

$f_{B}$ - compressive strength of bricks obtained in the tests.

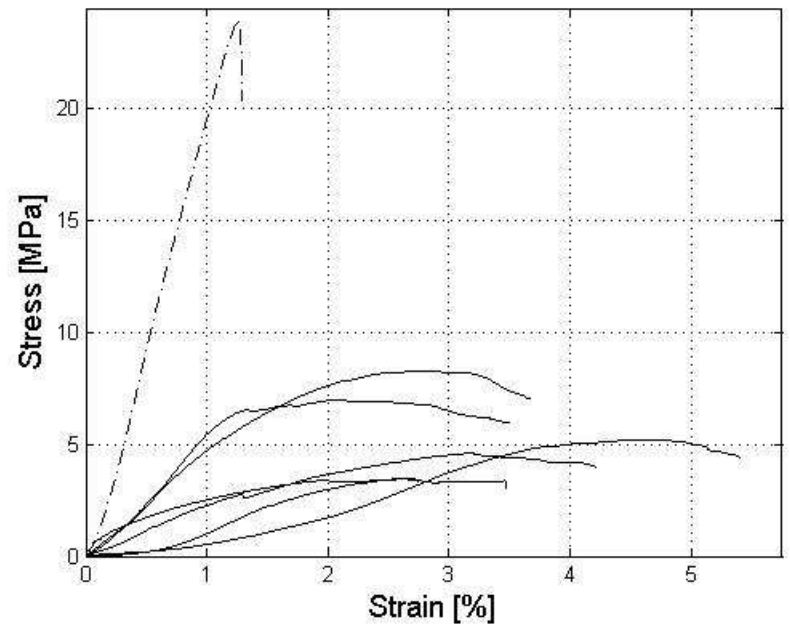

Fig. 3. Stress-strain curve $(\sigma-\varepsilon)$ of the tested bricks: dashed line - modern-day brick, solid line - bricks from the church

Taking samples of the mortar from the original construction without damaging it proved impossible. Thus mortar strength parameters provided in works [8] and [3] were taken into the analysis, i.e.: modulus of elasticity $E_{m}=0.96 \mathrm{GPa}$, strength $f_{m}=0.8 \mathrm{MPa}$. An analysis of the influence of the material parameters of mortar on the parameters of homogenized masonry wall was carried out. 
However, considering the mortar stiffness range provided in literature (e.g., Augenti [1]), no considerable influence was observed. This can also result from the not significant variability of mortar properties and quite large size of gothic bricks.

\section{HOMOGENIZATION}

Calculations of the modulus of elasticity of church walls as a homogenous material were carried out accordingly to the algorithm of homogenization proposed in work [2]. In this method, an elementary cell is analyzed, where based on strain compatibility and stress balance equations of its components, the basic material properties of the entire element can be calculated.

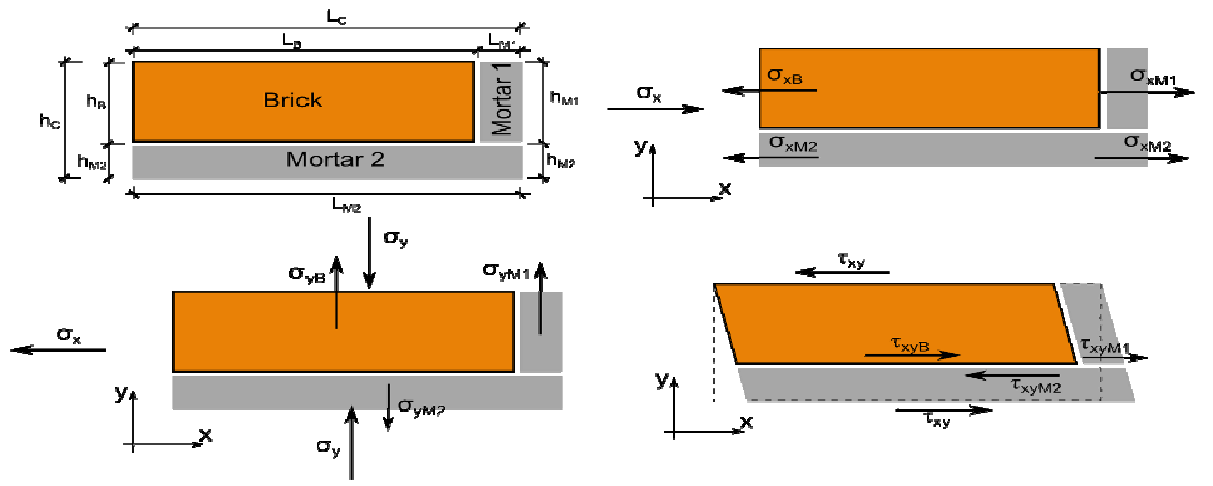

Fig. 4. Elementary cell and stress balance in individual states

The basic assumptions of this method are:

- The width and height of a elementary cell is greater than its thickness, which makes it possible to assume a plane stress state in the wall,

- A regular layout of bricks and joints in the wall,

- Small stress gradient in the construction, lack of stress concentrations.

Horizontal stress balance equations $\sigma_{x}$ can be presented in the following form (2):

$$
\begin{aligned}
& \sigma_{x} h_{C}=\sigma_{x B} h_{B}+\sigma_{x M 2} h_{M 2}=\sigma_{x M 1} h_{M 1}+\sigma_{x M 2} h_{M 2} \\
& \sigma_{x}=\sigma_{x B} \frac{h_{B}}{h_{C}}+\sigma_{x M 2} \frac{h_{M 2}}{h_{C}} \\
& \sigma_{x}=\sigma_{x M 1} \frac{h_{M 1}}{h_{C}}+\sigma_{x M 2} \frac{h_{M 2}}{h_{C}} \\
& \sigma_{x B}=\sigma_{x M 1}
\end{aligned}
$$


where: $\sigma_{i j}$-stresses in the $i$-th direction of the $j$-th component,

$h_{j}$ - height of $j$-th component.

The agreement of strains $\varepsilon_{x}$ in the horizontal direction can be represented by formula (3):

$$
\varepsilon_{x C}=\varepsilon_{x M 2} \frac{L_{M 2}}{L_{C}}=\varepsilon_{x B} \frac{L_{B}}{L_{C}}+\varepsilon_{x M 1} \frac{L_{M 1}}{L_{C}}
$$

where: $\varepsilon_{i j}$ - strains in the $i$-th direction of the $j$-th component, $L_{j}$ - width of j-th component.

A precise description of the method can be found in work [2] as well as in the works of other authors, e.g.[8].

The moduli of elasticity of the brick wall in two directions perpendicular to each other calculated accordingly to this algorithm are $E_{x}=2.374 \mathrm{GPa}$ and $E_{y}=2.120 \mathrm{GPa}$ respectively. Matysek and Witkowski in their work [3] obtained a modulus of elasticity of 1.0-2.4 GPa (average value of $1.6 \mathrm{GPa}$ ) in their studies on XIX century walls, thus it can be observed that the value obtained in the present work falls within the range limits provided in literature.

Based on empirical relationships provided by Matysek in [4], the compressive strength of a masonry wall was determined according to the following formula:

$$
f_{k}=\chi \cdot 0.36 \cdot f_{b}^{0,7} \cdot f_{m}^{0,3}=0,8 \cdot 0.36 \cdot 4.537^{0,7} \cdot 0.8^{0,3}=0.776 \mathrm{MPa}
$$

where: $f_{k}$ - compressive strength of wall,

$\chi$ - coefficient accounting for the characteristics of a historic wall,

$f_{b}$ - compressive strength of bricks,

$f_{m}$ - compressive strength of mortar.

Strength parameters calculated in such a way were applied to calculations of the homogenized walls of the church in Gnojewo, which will be the subject of further research undertaken by the team.

\section{VERIFCATION OF HOMOGENIZATION}

The accuracy of used homogenization logarithms was verified performing numerical simulations of the static behavior of micro- and macromodels of the bent masonry deep beam (Fig. 5) given by Page and described in [6]. This deep beam was loaded midspan using a steel beam, applying a force of 20,40, 60, 80 and $100 \mathrm{kN}$; the present work shows the results of loading with a force of $20 \mathrm{kN}$. 
The experimental data presented in [6] were repeatedly applied to verify the procedure of homogenization, among others by Quinteros et al. [8]. In the study we followed the same procedure. The models were created using the Abaqus 6.10 FEM software. The studies of Page described in work [6] were preceded by detailed tests of the material. Values of strength parameters of brick and mortar as well as their dimensions were applied in our FEM model behavior simulations. The parameters of the homogenized material of the masonry deep beam were obtained using the homogenization method presented in Chapter 3. A so-called micromodel was created, in which bricks and mortar were modeled individually. A mesh of finite elements based on solid hexagonal elements with a linear shape function marked as C3D8R was used; the finite element size was applied as equal to the thickness of the mortar, i.e. $5 \mathrm{~mm}$.

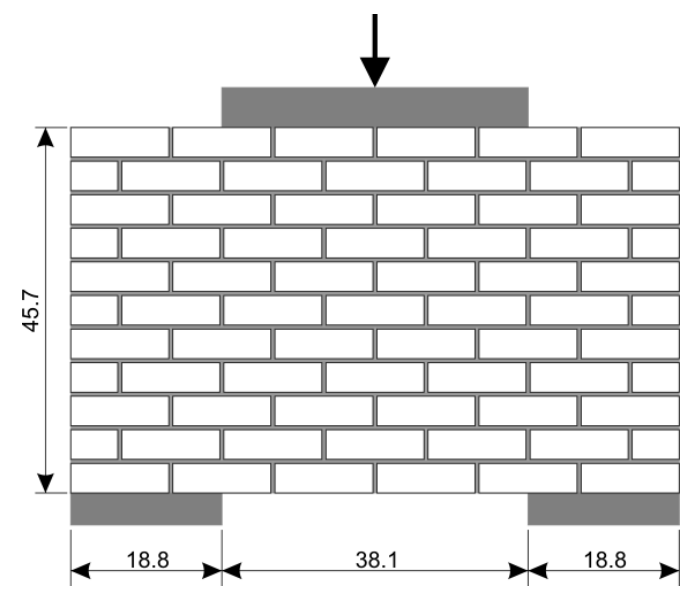

Fig. 5. Masonry deep beam studied by Page [6], measurements in [cm]

A series of macromodels was carried out, in which homogenized wall parameters were used. In these models, a mesh of solid hexagonal finite elements with a linear shape function marked as C3D8R was also built. Calculations were carried out assuming the following finite element size: 40 $\mathrm{mm}, 20 \mathrm{~mm}, 10 \mathrm{~mm}$ and $5 \mathrm{~mm}$. Convergence of the solutions was assessed comparing the displacements of the central point on the lower surface of the panel.

Graphs of primary stresses along the line running through the middle of the panel have been shown in (Fig. 7). The graph allows one to compare the values of stresses obtained by other researchers and in experimental studies [6] with results of the present work (macromodel). It also presents the results of stresses obtained in the analysis of the micromodel and macromodel with the same mesh 
density. In the micromodel, jumps in stress are noticeable in the layers of mortar.
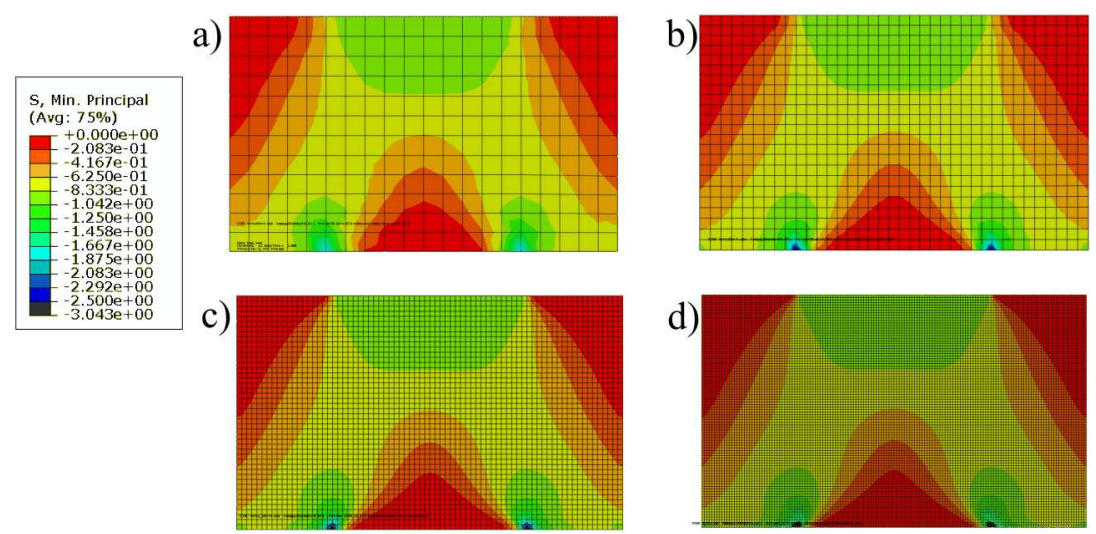

Fig. 6. Macromodels of masonry deep beam, mesh and maximum stress on a deformed model at a mesh density of a) 40, b) 20 , c) 10 and d) $5 \mathrm{~mm}$
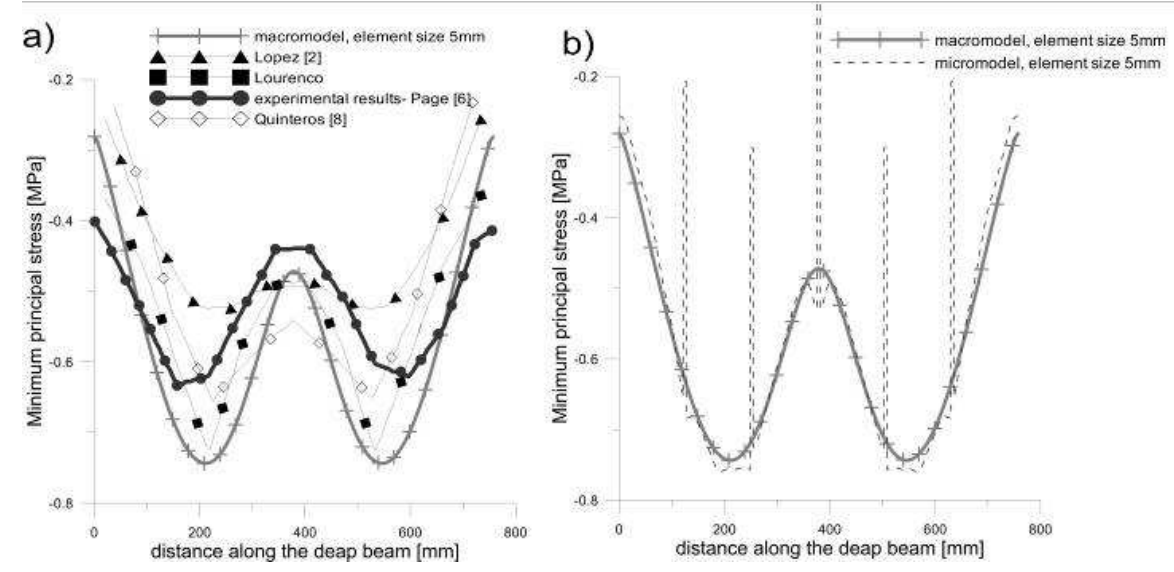

Fig. 7. Principal stress along the middle line of the masonry deep beam

An analysis of the outlined model applying the extended finite element method (XFEM) which makes the analysis of cracks possible without the necessity of applying remeshing methods, was also carried out.

\section{CONCLUSIONS}

The strength parameters of bricks from the original structure fall into the range obtained in other works concerning historical bricks (e.g. [5]), although they differ significantly from the parameters of modern-day bricks. 
The analysis of FEM numerical models using homogenized wall parameters indicates a strong similarity of these results to the results of other researchers. On the basis of graphs (Fig. 7), it can be stated that the method of homogenization was applied properly, and gave results which coincide with the micromodel (Fig. 7b) and experimental outcomes, as well as the results of numerical simulations carried out by other researchers (Fig. 7a). Thus it allows one to use the obtained results in modeling the brick walls of the church in Gnojewo while applying homogenized parameters, which is to be the aim of the research team's further studies.

\section{ACKNOWLEDGMENTS}

The authors gratefully acknowledge the technical support of the Emilia Malanowicz Foundation for the Preservation and Salvage of Monuments and Arteco Group.

\section{REFERENCES}

1. Augenti N., Parisi F.: Constitutive models for tuff masonry under uniaxial compression, Journal of Materials in Civil Engineering, 22, 11 (2010) 11021111.

2. Lopez J., S. Oller S., Oñate E., Lubliner J.: A homogeneous constitutive model for masonry, International Journal for Numerical Methods in Engineering, 46, 10 (1999), 1651-1671.

3. Matysek P., Witkowski M.: Badania wytrzymałości i odkształcalności XIXwiecznych murów ceglanych, XXVI Konferencja Naukowo-Techniczna Awarie Budowlane, Międzyzdroje 2013, 183-190.

4. Matysek P.: Uwagi o szacowaniu wytrzymatości murów zabytkowych na podstawie wytrzymałości cegiet $i$ zaprawy, Materiały budowlane, 457, 9 (2010), 44-51.

5. Modena C, Valluzzi MR, Tongini Folli R, Binda L. Design choices and intervention techniques for repairing and strengthening of the Monza cathedral bell-tower, Construction and Building Materials, 16, 7 (2002), 385-95.

6. Page A.: Finite element model for masonry. Journal of the Structural Division, 104, 8 (1978), 1267-1285.

7. Sieczkowski J., Szołomicki J.: Metody obliczeń statycznowytrzymatościowych sklepień $w$ budowlach gotyckich, Wrocław, Oficyna Wydawnicza Politechniki Wrocławskiej 1999 
8. Quinteros R., Oller, S., Nallim, L.: Nonlinear homogenization techniques to solve masonry structures problems. Composite Structures, 94, 2(2012), 724-730.

\section{PARAMETRY WYTRZYMAŁOŚCIOWE MURÓW CEGLANYCH W MODELOWANIU KONSTRUKCJI ZABYTKOWYCH}

\section{Streszczenie}

W artykule przedstawiono metodę określania podstawowych parametrów wytrzymałościowych zabytkowego muru ceglanego. Zastosowano badania eksperymentalne, aby określić podstawowe parametry wytrzymałościowe cegieł. Uzyskane wyniki porównano $\mathrm{z}$ wartościami wymienianymi w literaturze. Tak uzyskane wartości wprowadzono do algorytmów homogenizacyjnych umożliwiających obliczenie parametrów wytrzymałościowych muru jako materiału jednorodnego (zhomogenizowanego). Poprawność wykorzystanych metod zweryfikowano opracowując modele numeryczne MES wykorzystujące uzyskane parametry zhomogenizowanego materiału. Zbadano zbieżność modeli o rozmiarach elementów skończonych 40,20, 10, i $5 \mathrm{~mm}$. Wyniki uzyskane z modeli zhomogenizowanych oraz mikromodelu porównano $\mathrm{z}$ wynikami uzyskanymi przez innych badaczy oraz $\mathrm{z}$ wynikami eksperymentalnymi.

Słowa kluczowe: mury ceglane, zabytki, homogenizacja, modelowanie MES

Editor received the manuscript: 15.01 .2015 
